\title{
Business Governance in Brazil and South Africa: How Much Convergence to The Anglo-Saxon Model?**
}

\author{
Governança comercial no Brasil e na África do Sul: \\ quanta convergência para o modelo anglo-saxão?
}

ANDREA E. GOLDSTEIN**

\begin{abstract}
RESUMO: O efeito da globalização nas estratégias econômicas e políticas nacionais é um tema central na análise de políticas. No centro desse debate está a governança de negócios, interpretada neste documento em um sentido amplo como as leis, regras e rotinas que governam as grandes empresas. Segundo a sabedoria convencional, os padrões internacionais de governança de negócios estão convergindo para o chamado modelo anglo-saxão, orientado pelo mercado de capitais. Neste artigo, analiso mudanças recentes no Brasil e na África do Sul, para concluir que os modelos de governança de negócios devem ser vistos em conjunto com os fundamentos institucionais da economia. Isso inclui tradições jurídicas que dificilmente sofrerão mudanças rápidas, outras características institucionais diretamente relacionadas às maneiras pelas quais primeiro competem na economia global e os mecanismos pelos quais os atores sociais resistem a mudanças adversas aos seus interesses. PALAVRAS-CHAVE: Governança corporativa; privatização; regulação.
\end{abstract}

ABSTRACT: The effect of globalization on national economic and political strategies is a central theme in policy analysis. At the core of this debate is business governance, interpreted in this paper in a wide sense as the laws, rules, and routines that govern large-scale corporations. Conventional wisdom has it that cross-national patterns of business governance are converging on the so-called Anglo-Saxon, capital-market driven model. In this paper I analyze recent changes in Brazil and South Africa, to conclude that models of business governance should be seen jointly with the institutional underpinnings of the economy. These include legal traditions that are unlikely to undergo rapid changes, other institutional features directly related to the ways in which first compete in the global economy, and the mechanisms through which social actors resist changes adverse to their interests.

KEYWORDS: Corporate governance; privatization; regulation.

JEL Classification: K22; G34.

\footnotetext{
* I thank Luiz Carlos Bresser-Pereira, Peter Kingstone, Sylvia Maxfield, David O’Connor, and seminar participants at the 2000 meeting of the Latin American Studies Association, panel on "Competitive International Economic Strategies in Latin America", for most useful comments on earlier drafts. The opinions expressed and arguments employed remain my sole responsibility, and do not reflect those of the OECD Development Centre or its member countries.

** OECD Development Centre, Paris, France. E-mail: andrea.goldstein@oecd.org.
} 
The effect of globalization on national economic and political strategies is a central theme in policy analysis and debates in both OECD and non-OECD countries. Are rising levels of trade, capital flows, direct investment, communications technologies, managerial education, and market deregulation forcing all societies to converge towards the same rules, structures, and institutions for organizing economic, and more in particular corporate, life? Or can distinctive varieties of capitalism survive? And if so, what explains the different ability and willingness of political elites to attempt interventionist strategies aimed at molding the trajectory of capital accumulation?

At the core of this debate is business governance, interpreted in this paper in a wide sense as the laws, rules, and routines that govern large-scale corporations. This definition encompasses both corporate governance and broader issues regarding the private-public mix in the economy - privatization in primis, but also competition policy and the role of governments in the relationship between labor and capital. Other elements that obviously have an impact, including trade, industrial, and innovation policies, are not directly considered in this paper. Conventional wisdom has it that cross-national patterns of business governance are converging on the so called Anglo-Saxon, capital-market driven model. This is characterized by privatization, separation between ownership and control, unbundling of non-core assets by conglomerates, predominance of the goal of creating shareholder value over any other possible objectives of the enterprise, and more in general, market liberalization. At the risk of over-simplification, this hypothesis is predicated on the basis of two separate lines of reasoning. On the one hand, governments have to open up their markets to satisfy the desires of their domestic constituencies, and companies have to forfeit any aspiration at playing a role in society other than that of maximizing profits. On the other hand, increasing capital mobility will lead to a convergence of productivity growth rates and required rates of return on capital. The rules and institutions of world economic governance forcefully push towards the adoption of the so-called Washington consensus. National authorities cannot row against the ride: at best they can try to manage exchange rate fluctuations, but certainly they should not dare challenge the global wisdom that political, social, and historical considerations have no role to play in the way corporations are managed.

Models of business governance, however, cannot be seen in isolation from the rest of the institutional underpinnings of the economy (Guillén 1999). First, corporate governance is tightly coupled with legal traditions that are unlikely to undergo rapid changes (Bebchuck and Roe 1999). Second, corporate governance models interact in complex ways with other institutional features directly related to the ways in which firms compete in the global economy. The degree of investor protection, for example, is correlated with high employment protection (Pagano and Volpin 1999). Third, the variety of economic, social and political actors involved in corporate governance across countries makes it hard to envision convergence as the result of global pressures because they may attempt to shape and oppose changes adverse to their interests. Finally, if different corporate governance systems are associated with peculiar managerial decision -making criteria, temporal orienta- 
tions, and diachronic responses to the business cycle, the chances that stock markets in the world are uncorrelated with each other increase with the diversity in patterns of corporate governance. Uncorrelated stock markets enrich the menu for diversification because they provide greater opportunities for global portfolio investment. In this paper I analyze recent changes in the organization of big business in Brazil and South Africa. Despite cultural differences and the pervasively British character of its political, commercial, and legal institutions, in terms of income levels and distribution South Africa has more in common with the large industrialized countries of Latin America (especially Brazil) than it has with any other emerging region. In both countries the big business scene has been dominated by closely controlled private groups and state-owned enterprises, although mining still accounts for a far larger share of GDP in South Africa, a contrast that is even more marked when looking at the sector's participation in stock market capitalization. Similarities wear a bit thinner when it comes to monetary and fiscal policy and macroeconomic stability. South Africa has had a far better long-term track record in inflation control and fiscal discipline, although its record deteriorated during the late 1980s just as Latin America was about to improve its performance dramatically.

A roadmap to this paper. Section 1 presents a snapshot picture of the largest corporations in the mid-1980s and provides some historical background of the political economy of the rise of big business. Section 2 analyzes changes in the regulatory framework confronting big business in the wider context of the marketfriendly reforms implemented since the early 1990s. Section 3 scrutinizes the emergence of new domestic players. Section 4 concludes by identifying policy issues where Brazil and South Africa have adopted autonomous approaches and focuses on the reasons why they have not fully converged on the Anglo-Saxon model.

\section{A SHORT OVERVIEW OF THE POLITICAL ECONOMY OF BIGBUSINESS}

\section{Brazil}

Table 1 shows the ranking of the largest non-financial corporations in the two countries in 1984, based on the annual publications of Conjuntura Econômica and Financial Mail. In Brazil, the most important feature was the predominance of federal and state government ownership, especially in the top 25 list (17 companies) although slightly less so in the top 40 (19 companies). In 1984 domestic and foreign private companies were much smaller - the largest firms rank $8^{\text {th }}$ and $16^{\text {th }}$, respectively - but still rather numerous (ten and 11 firms among the top 40). The largest foreign firms produced consumer durables and industrial commodities, mostly petrochemicals.

Intervening in three broad areas - public services, non-renewable natural resources, and some manufacturing industries where private entrepreneurship was not forthcoming - the state did not aim at maintaining an autonomous intervention, nor at competing directly with private business, but rather at nurturing a "triple 
alliance" (tripé) with multinational corporations and local private entrepreneurs (Evans 1979). As import substitution industrialization erected barriers against imports, companies that opted for "tariff jumping" came to operate in an extremely protected environment in which domestic prices were well above those of the international market (Mesquita Moreira 1999). In this framework, private domestic capital also developed rent-seeking characteristics, with a low degree of genuine international competitiveness. Four Brazilian private companies in the list operate in the non-tradable sector, with the rest producing standard industrial commodities. Ownership and control firmly remained in the hands of the founding family: in the absence of pressures to improve efficiency and expand into the world market, cash flows were sufficient to finance limited investment needs. Brazilian enterprises tended to raise external capital through loans or issues of debtsecurities (such as debentures and bonds), rather than by issuing shares. Family control was further entrenched by interlocking directorates. An equally important obstacle to the development of a shareholder culture has been the content and application of corporate law (Armijo 1993). Opaque accounting discouraged outside investors from acquiring equity, including non-voting shares that are otherwise accorded preferential dividend treatment. The action of the stock market watchdog failed to do much in protecting investors and increasing confidence in the market. Given the high inflation environment, the quality of published balance sheets was also lower than the international norms. Forms of contractual savings are also very weak, since the payas-you-go pension system is public managed, and only covers the formal sector of the economy. Finally, changes of control usually happen through block trade and small shareholders cannot expect to benefit from the market for corporate control. Brazilian big business followed a relatively prudent strategy insofar as conglomeration was concerned, venturing into a lower number of lines of business than, for example, Korea's Samsung or India's Tata. ${ }^{1}$ While the large construction companies (empreiteiras), such as Andrade Gutierrez, Camargo Corrêa, Mendes Junior, and Odebrecht, invested in unconnected activities, as well as in foreign markets, they still mostly relied on public demand for large infrastructure projects. In terms of GDP share, Brazilian business groups, while important, have played a smaller role than in countries such as India, Korea, and Mexico (Singh 1995, p. 45). Reasons have included the limitations on banking-commerce links, the origins of many private banks in fínancing agricultural exports, and the early arrival of foreign companies on the Brazilian market. Low diversification, however, has increased vulnerability and made firms more likely to oppose shifts in policy priorities (Haggard et al. 1997).

\footnotetext{
${ }^{1}$ The most significant exceptions are the two largest private banks. Itaú and Bradesco acquired significant participations in non-financial enterprises, including electronics where, to be fair, they were among the world's earliest credit institutions to recognize the importance of extensively using information technology. This need is of course particularly large in high-inflation countries where overnight cash management is probably the most important determinant of corporate results
} 
Table 1: The largest non-financial corporations in 1984

\begin{tabular}{|c|c|c|c|c|c|c|}
\hline & BRAZIL & Owner & Sector & SOUTH AFRICA & Owner & Sector \\
\hline 1 & Petrobras & CG & $\mathrm{RM}$ & Escom & $C G$ & $U$ \\
\hline 2 & CVRD & CG & $\mathrm{RM}$ & Sats & CG & U \\
\hline 3 & CESP & SG & U & Anglo & PN & $\mathrm{RM}$ \\
\hline 4 & TELESP & CG & U & Remgro & PN & $\mathrm{D}$ \\
\hline 5 & Furnas & CG & U & Gencor & PN & $\mathrm{RM}$ \\
\hline 6 & CHESF & CG & U & Barlows & PN & $\mathrm{D}$ \\
\hline 7 & RFFSA & CG & $U$ & De Beers & PN & $\mathrm{RM}$ \\
\hline 8 & Copene & PN & IC & Sasol & CG & IC \\
\hline 9 & EMBRATEL & CG & $U$ & Iscor & CG & IC \\
\hline 10 & CEMIG & SG & U & Amgold & PN & $\mathrm{RM}$ \\
\hline 11 & Usiminas & CG & IC & GFSA & PF & $\mathrm{RM}$ \\
\hline 12 & SABESP & SG & $U$ & $\mathrm{SAB}$ & PN & CND \\
\hline 13 & Eletronorte & $\mathrm{CG}$ & U & Ltberty Holdings & PN & $\mathrm{D}$ \\
\hline 14 & Light & CG & U & CG Smith & PN & CND \\
\hline 15 & Petroquímica União & CG & IC & Amic & PN & $\mathrm{D}$ \\
\hline 16 & Mercedes Benz & PF & $C D$ & $\mathrm{JCl}$ & PN & $\mathrm{D}$ \\
\hline 17 & COPEL & SG & $U$ & IDC & CG & $\mathrm{D}$ \\
\hline 18 & Camargo Corrêa & PN & C & CGS Food & PN & CND \\
\hline 19 & Mendes Junior & PN & C & Vaal Reefs & PN & $\mathrm{RM}$ \\
\hline 20 & VARIG & PN & U & Premier Group & PN & CND \\
\hline 21 & TELERJ & CG & U & $\mathrm{AECl}$ & PN & IC \\
\hline 22 & Suzano & PN & IC & Sappi & PN & IC \\
\hline 23 & Belgo Mineira & PN & IC & Amscor & CG & $\mathrm{HT}$ \\
\hline 24 & Volkswagen & PF & $C D$ & Tongaat & PN & CND \\
\hline 25 & Petrobras Distribuidora & CG & CND & Senchem & PN & IC \\
\hline 26 & Mannesmann & PF & IC & Dries & PN & $\mathrm{RM}$ \\
\hline 27 & Rhodia & PF & IC & Metkor & PN & C \\
\hline 28 & Klabin & PN & IC & Federale Volk & PN & D \\
\hline 29 & Aracruz & PN & IC & Anglovaal & PN & $\mathrm{RM}$ \\
\hline 30 & Brasileira Alumínio & PN & IC & Tiger Oats & PN & CND \\
\hline 31 & Votorantim & PN & IC & ATI & PN & D \\
\hline 32 & Andrade Gutierrez & PN & $\mathrm{C}$ & Kisch & PN & CND \\
\hline 33 & Dow Química & PF & IC & Alpha & PN & C \\
\hline 34 & Eletrosul & CG & $U$ & Nampak & PN & IC \\
\hline 35 & Pirelli & PF & $C D$ & $M \& R$ & PN & $\mathrm{D}$ \\
\hline 36 & Nestlé & PF & CND & Plate & PN & $\mathrm{D}$ \\
\hline 37 & ESSO & PF & RM & Hiveld & PN & IC \\
\hline 38 & White Martins & PF & IC & OK & PN & CND \\
\hline 39 & Docenave & CG & $U$ & PPC & PN & $\mathrm{C}$ \\
\hline 40 & Ford & PF & $C D$ & Reunert & PN & $\mathrm{HT}$ \\
\hline
\end{tabular}

Ownership: $C G=$ central government; $S G=$ state government; $P F=$ private foreign; $P N=$ private national

Sectors: $\mathrm{C}=$ construction \& engineering; $\mathrm{CD}=$ consumer durables; $\mathrm{CND}=$ consumer non-durables \& distribution; $D=$ diversified; $H T=$ high-technology; $I C=$ industrial commodities; $R M=$ raw materials; $U=$ =utilities. 


\section{South Africa}

The firms associated with the traditional mining houses dominated the 1984 rankings of South African big business, with five companies in the top 11. Relative to Brazil, there has certainly been a greater emphasis on equity finance - not least because of the higher protection to investor rights provided by the common law system and the strength of contractual savings institutions - but the use of a pyramidalstructurehasallowed to combineownershipdiffusion insubsidiaries withconcentrated control of the holding company. In 1983, the six largest listed groups - Anglo, Rembrandt, Sanlam, Old Mutual, Liberty Life Insurance, and Anglovaal - accounted for two thirds of market capitalization. The exceptions were Sanlam and Old Mutual, until recently mutual organizations, owned by the holders of their insurance policies.

The larger weight of private domestic capital does not mean, however, that public ownership has not played a role in South African corporate history. In the second and third decades of the century, responsive to the needs of its Afrikaner constituency, the National Party created SOEs to develop a stable industrial base for white rule. SOEs were assigned three main policy goals: offset the economic dominance of the gold mining industry, provide some autonomy from foreign producers, and create jobs for Afrikaner workers (Clark 1994). The policy of "Afrikaner favoritism" also included direct assistance to private Afrikaner companies. Interlocking directorships with state corporations gave many Afrikaner undertakings a crucial inside edge. Government contracts and subsidies benefited particularly the Sanlam industrial investment subsidiary, Federale Volksbeleggings.

By the 1960s, mounting concerns about the sustainability of balance of payments deficits, decelerating growth, and increasing international isolation prompted the NPgovernment into "deepening" import-substitution. In sensitive and capital-intensive industries, such as steel, petrochemicals, and defense, SOEs took thelead.Sasol, in particular, was established for strategic reasons to convert indigenous coal into oil. A key role in this period was also played by the Armaments Development and Production Corporation (Armscor) and Denel, arms-producers established to counter the UN weapons embargo. The conglomerates tried to expand abroad within the limits made possible by exchange restrictions while also diversifying domestically.

\section{THE CONTEXT AND CONTENT OF MARKET-FRIENDLY REFORMS}

\section{Brazil}

Privatization and market liberalization were launched on a grand scale later than elsewhere in Latin America: as late as in 1993, opinion polls showed that the balance between those arguing for and against an increase in the role of the state still slightly tilted to the formers' advantage (Manzetti 1999, p. 181). Issued in 1990, the Programa Nacional de Desestatização (PND) clearly spelled out the objectives of privatization: 
- modify the nature of state's intervention;

- reduce public debt;

- increase investment;

- stimulate competition, and,

- strengthen the stock market.

Responsibilities have been tightly concentrated in a single agency, the BNDES, which depends on the government but is functionally independent. Despite its prointervention imprinting, the BNDES was chosen because it had accumulated an unsurpassed expertise and had started recognizing the opportunities which privatization opened to Brazil well before a consensus emerged in the rest of the elite. Moreover, BNDESPAR, its fully-owned investment bank, had been accumulating direct shareholdings in a number of important companies as a result of the conversion of non-performing loans.

Despite serious problems, total receipts realized during Fernando Collor's presidency, at slightly less than US\$ 4 billion, far outweighed those obtained in the previous decade. Following Collor's resignation, the new administration, headed by his vice-president Itamar Franco, initially froze the PND, but was then obliged to resume the program in the face of mounting fiscal concerns, finally leading to the almost complete exit of the state from manufacturing. During the presidency of Fernando Henrique Cardoso, moving on to public utilities and banks has been a key element of economic policy. Privatization also reached the state level, as governments entered into agreements with the Finance ministry to restructure decentralized debt on condition that they increase the primary surplus and sell public enterprises. A milestone was passed in May 1997 when the "strategic block" of CVRD - the world's largest iron ore producer and exporter, as well as one of the biggest aluminium and steel companies in Brazil - was sold to a consortium led by Companhia Siderúrgica Nacional (CSN), Latin America's biggest integrated steel maker. Another important achievement was the beginning, in 1997, of the privatization of the telecommunications sector. In July 1998, the federal government sold 12 holding companies created by the spin-off of the Telebrás System, which resulted in the transfer to the private sector of all the wireline and long-distance operators, as well as the "A" Band cellular operators. Following the granting of espelho concessions to compete with the former Telebrás holdings, the local duopoly will end in 2002 when entry will be unrestricted. As for competition policy, in the 1990s the Administrative Council for Economic Defense (CADE) was given more autonomy from the central administration and its members gained a fixed two-year term renewable once. The overall focus of competition shifted from direct intervention in the market for the purpose of protecting the so-called "popular economy" (i.e., essentially, controlling prices) to the analysis of mergers, abuse of dominant position, and other topics more in line with the international trends in antitrust regulation. The number of CADE decisions have increased tremendously, and rulings now mostly concern issues of conduct regulation such as cartels and abusive pricing (Oliveira 1998). Given the steep increase in merger and acquisition activity in Bra- 
zil, the CADE has also taken important decisions to prevent market abuses. ${ }^{2} 2$ Regulatory agencies have been also set up for telecommunications, electricity, and the oil sector and Congress approved in 1995 a law governing the central aspects of the provision of public utilities under license agreements. In March 1999 the National Telecommunications Agency (ANATEL) allocated the new codes for the multi-carrier system that allows consumers to choose their long-distance carrier. In February 2000 the telecoms regulator also ruled that Telefónica must either sell or surrender its controlling stake in CRT, the fixed telephone operator in the Rio Grande do Sul, since it bought Telesp, the fixed operator in São Paulo state.

\section{South Africa}

A heated debate has concerned the relationship between the apartheid system and South African conglomerates, and capitalism by extension. Apartheid secured a practically continuous flow of very cheap migrant black labor to white mines, farms, and factories and made investment choices that perpetuated inequalities: a good example has been the limited investments made by Eskom, the electricity company, in supplying rural areas and townships. It is far more contentious, however, whether the very survival of big business hinged on the control and repression of the black majority - in other words, whether "the institutions of apartheid were functional to capitalist development rather than a distortion of it" (Nattrass 1994a, p. 253). Lipton (1985) contends that the growth of the national economy increased the costs of the constraints and inefficiencies associated to apartheid, especially the shortage of skilled and educated labor, finally pushing the business community towards reform.

In the second half of the 1980s business entered into negotiations with the African National Congress (ANC) leadership in exile, opening a dialogue that led to Nelson Mandela's release in 1990 and ultimately to his election as president in 1994. Facing the challenge of promoting growth, reassuring investors, and appeasing its constituency, the ANC produced in 1990 the Discussion Document on Economic Policy (DDEP). Implicit in the program was the reference to the kind of government intervention that has been identified as crucial to the East Asian miracle. Nonetheless, applying such lessons to South Africa proved difficult. For example, while nationalization of mining houses and utilities remained firmly in the agenda, as did breaking up the conglomerates, no indication was provided about the means for achieving this and the likely consequences. On the other hand, the DDEP endorsed the principle of corporatization - i.e. tri-partite negotiation between government, business, and labor - a style of policy-making that had been conspicuously absent in East Asia. The National Development and Labour Council

\footnotetext{
${ }^{2}$ For example, it imposed various conditions on the acquisition by Colgate of Kolynos, a Brazilian toothpaste, including the obligation of suspending the use of the trademark and of making a public offer of toll manufacturing agreements to all existing or potential competitors in the tooth paste market. It also ordered two Brazil-American beer joint ventures to be dissolved on the ground that the Brazilian companies were using the tie-ups to limit competition from the American competitors, which could have entered the market independently.
} 
(NEDLAC) - a vehicle to seek quadri-partite (as the community constituency had been added) co-operation on economic, labor, and development issues - was launched in February 1995. NEDLAC has played a key role in allaying business fears about the risks of a populist derive, fears that were magnified in the aftermath of the 1994 elections by its relative lack of access to the new political leadership, the influence gained by many trade unionists, and the reshuffling of the civil service.

With the economy falling in a prolonged recession, it became clear that the balance of payments and the inflation danger would severely constrain any attempt to rapidly meet the expectations for the improvement of basic living needs. This progressively watered down the tone of ANC's declarations: for example the distinction between conglomeration - a structure of organizing business activity that was seen as inimical to the goals of redistribution - and large firms - that on the other hand were acknowledged as necessary for growth - was made explicit. Yet, two other principles persisted: the call for controls on financial institutions and subjecting any rolling back of government intervention to the goal of empowering the historically disadvantaged. In the run-up to the 1994 election, the Reconstruction and Development Programme (RDP) emerged as the center-piece of the ANC's platform. Its goals were incredibly ambitious - "embedding democracy; disentangling the costly and debilitating legacy of apartheid; accelerating economic growth and new opportunities; delivering affordable services equitably; and fundamentally transforming society, the economy and all spheres of government" (Goldin and Heymans 1999, p. 109). Yet the RDP was deliberately vague on ideological and technical considerations, as they were considered "secondary to the overriding concern of meeting human needs, in a sustainable manner" (ANC1992).

In the first quarter of 1996, however, the rand suffered a speculative attack. Acknowledging the need to enhance policy credibility to stem the reversal of capital flows, the government adopted an explicit macroeconomic framework. Adopted in June 1996, GEAR (Growth, Employment and Redistribution) recognizes that a sustained reduction in inequality requires accelerated job creation, which in tum requires structural transformation to achieve higher and more labor-absorbing growth within the economy. Above and beyond its weaknesses, and especially the possible inconsistency of its assumptions, GEAR marks a watershed insofar as it heralds the ANC's full acceptance of the need for "a brisk expansion in private sector capital formation". Its core elements are restructuring of the public sector, speeding up the restructuring of state assets, and accelerating the fiscal deficit reduction program.

At the time of the democratic transition in 1994, the major parastatals were generally characterized by capital starvation, over-borrowing, bureaucratic inertia, and managerial stagnation (Ministry for Public Enterprises 1999). The RDP did not explicitly mention privatization, although it saw receipts from state divestiture as a way to fund its objectives. Some SOEs were assigned RDP commitments. In GEAR the scope for public sector restructuring program is much wider and in 1998 the government set up a National Empowerment Fund (NEF), where a portion of the shares of each privatized enterprise will go, in order to reduce political opposition to state divestiture. Nonetheless, there have only been two deals of some global significance - the sale to strategic partners of equity stakes in Telkom (30\%) in 1997 
and South African Airways (20\%) in 1999. While there is a clear sense of continuity between the Mandela and the Mbekigovernments, the latter in power since mid-1999, privatization seems to have recently attained a higher policy priority. The Eskom Amendment Bill was passed, aiming to corporatize the electricity utility. Plans are also discussed to float Telkom in 2001. Finally, the Public Finance Management Act 1999 aims to secure transparency, accountability and sound management of public and semi-public institutions.

While competition policy was introduced in South Africa in 1955, it has been traditionally berated for its timidity to act decisively to combat market dominance by large firms. The issue of the concentration of economy-wide power in the hands of a few conglomerates, much more than the debate aboutcompetition policy per se, has taken center stage of the policy debate immediately after the end of apartheid. The 1992 ANC's Policy Guidelines for a Democratic South Africa heralded the intention to introduce "anti-monopoly, anti-trust and merger policies in accordance with international norms and practices, to curb monopolies and continued domination of the economy by a minority within the white minority, and to promote greater efficiency in the private sector". This mandate was made explicit by the RDP, which also mentions the systematic discouragement of the system of pyramidal companies where they lead to over-concentration of economic power and interlocking directorships.

The government presented its proposals in 1997, on the understanding that a uniquely South African approach to competition policy was required to provide a consistent framework conducive to the parallel goals of pursuing competitiveness and efficiency, and ensuring access to many more people previously denied an equal opportunity to participate in the economy. Following tripartite negotiations, the new Competition Act finally came into effect in September 1999. While the South African competition policy framework is consistent with international thinking and practice on the subject, the country's particular history charges it with sui generis social objectives, and has therefore raised controversial issues. On the one hand, the business community has criticized the inclusion of social goals in the Act; the underlying hostility towards conglomerates and cross-shareholdings; the fact that the onus is on the applicant to prove that a pro-competitive advantage will result from horizontal or vertical agreements; the granting of discretionary review powers over merger decisions to the Minister; and the vague criteria for the appointment of the Commission's officials. On the other hand, the trade unions have argued that the Act "simply promotes competition for its own stake" and does not go far enough in associating it with clearly stated developmental goals; that in attempting primarily to prevent anti-competitive conduct it does not explicitly introduce tools aimed at breaking up inherited patterns of concentrated ownership and control; that the scope of ministerial review discretion should be widened to intermediate mergers; and that the powers of the Commission and related institutions must be reinforced, for instance as concerns search and seizure. Too little time has elapsed from the passing of the Act, however.

As concerns regulatory reform in public services, progress has been far more limited. After an extensive public debate on the form that the new telecommunications regime in South Africa should take, the Telecommunications Act was promul- 
gated in 1996. The South African Telecommunications Regulatory Authority (Satra) was established in order to effectively regulate the telecommunications sector and to address the broad and comprehensive mandate prescribed in the Act. ${ }^{3}$ However, the Act does not put specific dates to the process of liberalization, so that key decisions are left to the discretion of the Minister. The Telkom exclusivity, which expires in May 2002, with a possible extension to 2003, is rather long by international standards. The main reason is that the company is required to provide new lines, mostly in rural areas, and to improve its consumer service levels. Faced with uncompetitive phone rates and the inability of the monopolist to meet all Satra semi-annual targets, big business circles have shown mounting frustration at the timidity of government's policies. In preparation for liberalization, interconnection guidelines were issued in June 1999, while a project for the new numbering plan is currently underway.

\section{THE NEW CONTOURS OF BIG BUSINESS}

\section{Brazil}

Between 1991 and 1998, the total volume of mergers and acquisitions (including privatization) in Brazil was equal to US\$ 142 billion (Siffert Filho and Souza e Silva 1999). Record interest in Brazil from multinationals from all OECD countries (and some non-OECD ones, notably Chile and Argentina, but also South Africa, as a matter of fact) has made Brazil the non-OECD's second largest recipient of FDI. Table 2 presents the ranking of the largest corporations in 1998. There are six companies completely controlled by multinationals in the top 40, of which three produce consumer durables. Of even greater numerical relevance are the eight utilities jointly controlled by foreign and Brazilian private capital. Overall, the multinationals' share in total sales by Brazil's 100 largest companies have increased from $26 \%$ to $40 \%$. Shared control between a ultiplicity of investors - domestic and foreign, industrial and financial, none of them having a majority in isolation - has become a key instrument of corporate control (Table 3). This strategy has been particularly important in the expansion of Grupo Vicunha, that in the space of a very few years has been transformed from Brazil's largest textile firm to the country's biggest business group, with interest in steel, CVRD, and various utilities (mobile-phone licenses for Bahia, electricity in Rio, railroads). Vicunha was prepared to borrow to win the privatization bids and to run the firms under a nucleus of shareholders - in contrast to the traditional preference of Brazil's family entrepreneurs to avoid debt and insist on total control in any venture.

\footnotetext{
${ }^{3}$ The National Electricity Regulator (NER) was established in March 1995, although its mandate is much more limited in view of the even less liberal regulatory regime. NER came under severe pressures in 1998, when the government decided to investigate human resources practices and alleged inancial irregularities within the agency.
} 
Table 2: The largest non-financial corporations in 1998

\begin{tabular}{|c|c|c|c|c|c|c|}
\hline & BRAZIL & Owner & Sector & SOUTH AFRICA & Owner & Sector \\
\hline 1 & Petrobras & CG & RM & Anglo & PN & $\mathrm{RM}$ \\
\hline 2 & Furnas & CG & $U$ & Eskom & CG & $U$ \\
\hline 3 & TELESP & PM & $U$ & Transnet & CG & $U$ \\
\hline 4 & CESP & SG & U & Sappi & PN & I C \\
\hline 5 & SABESP & SG & U & De Beers & PN & $\mathrm{R} M$ \\
\hline 6 & EMBRATEL & PM & U & Remgro & PN & $\mathrm{D}$ \\
\hline 7 & CVRD & PN & $\mathrm{RM}$ & Telkom & $\mathrm{CG}$ & u \\
\hline 8 & Fiat & PF & $C D$ & $\mathrm{SAB}$ & PN & CND \\
\hline 9 & Eletropaulo & PM & $U$ & Anglo Gold & PN & $\mathrm{RM}$ \\
\hline 10 & RFFSA & CG & U & Sasol & PN & IC \\
\hline 11 & CEMIG & SG & U & CG Smith & PN & CND \\
\hline 12 & CSN & PN & IC & Nail & PN & $\mathrm{H}$ \\
\hline 13 & Light & PN & $U$ & Barlows & PN & $\mathrm{D}$ \\
\hline 14 & CBD & PN & CND & Goldfields & PN & $\mathrm{RM}$ \\
\hline 15 & CHESF & CG & $U$ & Iscor & PN & IC \\
\hline 16 & Usiminas & PN & IC & Johnnic & PN & $\mathrm{H}$ \\
\hline 17 & Brahma & PN & CND & Avmin & PN & $\mathrm{RM}$ \\
\hline 18 & Petrobras Distribuidora & CG & $\mathrm{RM}$ & Tiger Oats & PN & CND \\
\hline 19 & Mercedes Benz & PF & $C D$ & GFSA & PN & $\mathrm{RM}$ \\
\hline 20 & COPEL & SG & $U$ & Pepkor & PN & CND \\
\hline 21 & CPFL & PM & $U$ & Minorco & PN & $\mathrm{RM}$ \\
\hline 22 & TELERJ & PM & U & Billiton & PN & RM \\
\hline 23 & TELESP Celula $r$ & PF & U & Amplats & PN & $\mathrm{RM}$ \\
\hline 24 & VARIG & PN & U & $M \& R$ HId & PN & $\mathrm{H}$ \\
\hline 25 & Eletronorte & CG & $U$ & FIT HId & PN & $\mathrm{H}$ \\
\hline 26 & COSIPA & PN & IC & $A V I$ & PN & $\mathrm{D}$ \\
\hline 27 & Ceval & PN & IC & Imperial & PN & CND \\
\hline 28 & Gerdau & PN & IC & Kersaf & $\mathrm{PN}$ & CND \\
\hline 29 & CST & PN & IC & $\mathrm{AECl}$ & PN & IC \\
\hline 30 & Shell & $\mathrm{PF}$ & $\mathrm{RM}$ & Tongaat & PN & $\mathrm{DI}$ \\
\hline 31 & Bandeirante & PM & U & Amgold & PN & $\mathrm{R} M$ \\
\hline 32 & Credicard & PN & CND & Dries & PN & $\mathrm{RM}$ \\
\hline 33 & Ericson & PF & $\mathrm{CD}$ & Wooltru & PN & CND \\
\hline 34 & So za Cruz & PF & CN D & Implats & PN & $\mathrm{R} M$ \\
\hline 35 & Copene & PN & IC & Comparex & PN & $\mathrm{HT}$ \\
\hline 36 & TELEMIG & PM & $U$ & Shoprite & PN & CND \\
\hline 37 & VASP & PN & U & Hiveld & PN & IC \\
\hline 38 & CEDAE & SG & U & Trencor & PN & CND \\
\hline 39 & CRT & PM & U & Richemont & PN & DI \\
\hline 40 & Ipiranga & PN & $\mathrm{RM}$ & Gencor & PN & $\mathrm{RM}$ \\
\hline
\end{tabular}

Ownership: $C G=$ central government; $S G=$ state government; $P F=$ private foreign; $P M=$ private mixed $d ; P N=$ private national Sectors: $C=$ construction: $C D=$ consumer durables: $C N D=$ consumer non-durables; $D=$ diversified: $\mathrm{H}=$ holding: IC=industrial commodities: IT=information technology; $\mathrm{RM}=$ raw materials; $\mathrm{U}=$ =utilities 
Table 3: Ownership of the 100 Largest Non-Financial Brazilian Companies

(percentage share of total revenues for the 100 largest companies)

\begin{tabular}{ccccccc}
\hline & $\begin{array}{c}\text { Dispersed } \\
\text { Ownership }\end{array}$ & $\begin{array}{c}\text { Shared } \\
\text { Control }\end{array}$ & $\begin{array}{c}\text { Family } \\
\text { Ownership }\end{array}$ & $\begin{array}{c}\text { Government } \\
\text { Ownership }\end{array}$ & $\begin{array}{c}\text { Foreign } \\
\text { Ownership }\end{array}$ & Cooperatives \\
\hline 1990 & 1 & 5 & 27 & 38 & 27 & 2 \\
& $(1)$ & $(4)$ & $(23)$ & $(44)$ & $(26)$ & $(2)$ \\
1995 & 3 & 15 & 26 & 23 & 31 & 2 \\
& $(2)$ & $(11)$ & $(17)$ & $(30)$ & $(38)$ & $(2)$ \\
1997 & 3 & 19 & 23 & 21 & 33 & 1 \\
& $(2)$ & $(12)$ & $(16)$ & $(32)$ & $(37)$ & $(0)$ \\
1998 & 4 & 23 & 26 & 12 & 34 & 1 \\
& $(3)$ & $(19)$ & $(17)$ & $(21)$ & $(40)$ & $(0)$ \\
\hline
\end{tabular}

Source: Siffert Filho, N. and C. Souza e Silva (1999), " Large Companies in the 1990s ; Strategic Responses to a Scenario of Change ", mimeo, BNDES Economics Department.

Politically, the larger the number of actors acquiring an interest in privatization, the stronger the coalition that backs the government when opposition from other groups, such as workers and suppliers, emerge. The coalition model of control allowed to associate employees as investors, usually with a seat on the board, and to appease nationalistic fringes through the participation of public-sector banks, foundations, and pension funds. The latter, in particular, invested over 1,400 US\$ million between 1991 and 1995. Economically, this strategy responded to the death of the domestic capital market and to the limited interest initially shown by business groups, notably in steel, and by foreign investors, notably in petrochemicals. In the longer term, however, this strategy may very well result inappropriate. The pension funds of the largest SOEs are not shielded from political pressures. For example, the president of Previ is appointed by the president of Banco do Brasil, himself one of the key political appointments decided by the government. In the past, such funds, which are rather lightly supervised by the Social Security Ministry (and not by financial market supervisors) accumulated huge losses by investing in politically-motivated ventures. At the present stage the risk is that political pressures may push SOEs' pension funds to acquire excessive power, although the opposite is also possible - in 1993 president Franco, a long-time opponent of privatization, decided to disqualify them from taking part. Therefore, while the presence of semipublic pension funds in the winning consortium may reassure those private (sometimes foreign) groups to which they are allied, it may be seen with far greater suspicions by institutional investors which keep an arms' length relationship. The government responded to these concerns by limiting to $25 \%$ the total amount of consortia bidding in privatization that can be owned by pension funds.

The PND explicitly lists the creation of people's capitalism among its main goals. Nonetheless, faced with low liquidity on the domestic market, about 100 Brazilian firms have already made their shares available in the United States in the form of American Depository Receipts (ADRs), although none has sought a primary listing abroad. Trading will be further reduced by the decision of Telefónica to buy all the 
shares it does not already own in Telesp and Tele-Sudeste Celular, that jointly accounted for about $10 \%$ of trading on the Bovespa. If pulverização has so far remained on wish lists, although the government is considering doing this when it sells a 34\% holding in Petrobrás, selling state assets to small investors without guaranteeing efficient separation of ownership and management would be inefficient. Recent measures aimed at stimulating the purchase of shares include a BNDES program to offer credit for the purchases of shares during privatizations, IPOs, and capital increases; the possibility for workers to participate in privatization by using savings accumulated in the FGTS (Fundo de Garantia do Tempo de Serviço) - a fund where employees compulsorily deposit part of their salary to cover against unemployment risk - to buy shares in ad hoc mutual funds (Fundo Mútuo de Privatização); and the establishment of complementary individual pension funds (Fundo de Aposentadoria Programada Individual). Corporate law was also modified. The 1997 Lei Kandir, which eliminated the obligation of tendering for all shares when the control stake in a listed company changes hands, elicited some controversy, although it was needed in order to speed up privatization. Other recent events, however, cast some doubts about the degree of protection that minority investors receive. In a significant case in 1998, the securities regulator probed the purchase of Lojas Renner a family-controlled retail group, by J.C. Penney. The CVM took action following complains from minority investors that they were treated unfavorably by the buyer. This shows that, in the trade-off between assuring the stability of control and protecting the rights of small shareholders, the balance still remains heavily biased toward the former.

\section{South Africa}

At first glance, little has changed in the contours of South African big business between 1984 and 1998. Raw materials producers continue to dominate the ranking (13 companies), and if anything has changed it is that mining houses have an even larger presence. Public sector utilities also have an important weight among the top 10 companies, as have diversified groups and holding companies (nine overall, as opposed to ten in 1984). Compared to Brazil, the little role played by privatization is indeed the most striking feature, especially insofar as few sell-offs have translated into scarce FOI flows.

Nonetheless, it would be disingenuous to evaluate the results of South Africa's divestiture policy solely in terms of receipts. As Goldin and Heymans (1999) tellingly put it, "South Africa's political culture over the past decades, and specifically the institutional fabric that emerged from the struggle against apartheid, cannot be accommodated merely with conventional representative structures" (p. 119). Specific policy actions with respect to black economic empowerment have been taken in the framework of the legislation governing privatization and competition. The 1996 Labour Ministry's Green Paper required companies to adopt governmentsanctioned employment equity plans, while the new public procurement policy requires consortia to make $40 \%$ of equity available to black partners and to subcontract $25 \%$ of work to emerging businesses. Black capital's participation in own- 
ership has also been facilitated by the introduction of special purpose vehicles (SPVs), whereby financial institutions provided funding to black entrepreneurs, who in turn offered as collateral preference equity capital in the companies acquired. More than half of black ownership on the JSE was created via SPVs. Finally, and possibly even more importantly, South African conglomerates, and Anglo in particular, have pursued an aggressive strategy of voluntary unbundling. While the refocusing on core business has followed from the need to insure competitiveness against the background of the opening of the domestic economy to world competition and weaker gold and commodity prices, voluntary unbundling has been an expedient strategy to appease the possible rise of nationalization sentiments. In order to build up a black capitalist constituency, it was important to conclude highly visible and large-scale deals. The first such deal was Sanlam's sale of Metropolitan Life (METLIFE), an insurance company, to New Africa Investment Ltd (NAIL). In 1996 Anglo broke up its majority-owned sub-holding JCI (Johannesburg Consolidated Investment) into platinum (Amplats), a homonymous mining subsidiary, and an industrial arm, Johnnic.

Table 4: History of group control of companies listed on the JSE

\begin{tabular}{|c|c|c|c|c|c|c|c|c|c|c|c|c|c|c|c|}
\hline \multicolumn{2}{|l|}{1983} & \multirow{2}{*}{$\frac{1984}{54.1}$} & \multicolumn{2}{|c|}{19851986} & \multirow{2}{*}{$\begin{array}{l}1987 \\
60.1\end{array}$} & \multirow{2}{*}{$\frac{1988}{49.5}$} & \multirow{2}{*}{$\begin{array}{l}1989 \\
45.3\end{array}$} & \multirow{2}{*}{$\begin{array}{r}1990 \\
44.2\end{array}$} & \multirow{2}{*}{$\begin{array}{l}1991 \\
42.4\end{array}$} & \multirow{2}{*}{$\begin{array}{l}1992 \\
33.7\end{array}$} & \multicolumn{2}{|c|}{19931994} & \multicolumn{3}{|c|}{199519961997} \\
\hline Anglo & 52.5 & & 53.6 & 54.1 & & & & & & & 38.2 & 43.3 & 37.1 & 28.3 & 22.6 \\
\hline Sanlam & 9.4 & 10.7 & 12.2 & 11.3 & 10.7 & 10.8 & 9.5 & 13.2 & 13.2 & 15.6 & 12.0 & 10.5 & 12.4 & 11.0 & 10.6 \\
\hline Rembrandt & 2.1 & 2.8 & 3.8 & 4.4 & 4.3 & 7.6 & 16.1 & 13.6 & 15.2 & 14.6 & 15.5 & 13.0 & 7.8 & 10.6 & 9.9 \\
\hline Old Mutual & 0.6 & 2.7 & 10.6 & 10.9 & 8.0 & 9.8 & 9.8 & 10.2 & 10.4 & 14.2 & 10. 7 & 9.7 & 11.2 & 10.2 & 11.4 \\
\hline Liberty & 1.1 & 2.1 & 2.0 & 2.3 & 2.0 & 2.6 & 3.4 & 2.6 & 3.7 & 4.7 & 6.2 & 7.2 & 7.3 & 11.1 & 11.9 \\
\hline Anglovaal & 1.7 & 1.7 & 2.1 & 2.1 & 2.1 & 2.4 & 2.2 & 2.2 & 2.5 & 2.9 & 3.4 & 3.6 & 2.9 & 3.0 & 1.5 \\
\hline Foreign control & 5.4 & 5.7 & 5.9 & 6.1 & 4.1 & 5.1 & 3.6 & 2.1 & 1.9 & 2.2 & 2.4 & 2.2 & 4.1 & 4.1 & 4.0 \\
\hline Mgm't control & 4.1 & 5.1 & 3.0 & 3.5 & 3.7 & 6.9 & 4.9 & 5.0 & 6.2 & 6.8 & 7.7 & 7.0 & 7.5 & 6.6 & 7.4 \\
\hline Black control & - & - & - & - & - & - & - & - & - & - & - & - & 0.6 & 6.3 & 9.3 \\
\hline Other groups & - & - & - & - & - & - & - & - & - & - & - & - & 3.4 & 4.1 & 6.1 \\
\hline Joint control & - & - & - & - & - & - & - & - & - & - & - & - & 2.4 & 1.5 & 1.3 \\
\hline Unallocated & 19.9 & 12.8 & 4.0 & 1.2 & 1.8 & 2.8 & 1.3 & 3.2 & 3.9 & 5.0 & 3.5 & 3.4 & 3.9 & 3.2 & 4.0 \\
\hline $\begin{array}{l}\text { Memorandum } \\
\text { Cumulated } \\
\text { share by }\end{array}$ & & & & & & & & & & & & & & & \\
\hline top 5 & 65.7 & 72.4 & 82.2 & 83.0 & 85.1 & 81.2 & 80.3 & 83.8 & 84.9 & 82.8 & 82.6 & 83.7 & 82.3 & 78.2 & 66.4 \\
\hline
\end{tabular}

Source: McGregor's (various years), Who Owns Who in South Africa.

The results of black economic empowerment have been prima facie encouraging, although certainly not staggering. Black capital share in total ownership of listed companies has risen from less than 1\% in 1995 to $9.3 \%$ in 1997 (Table 4). Nonetheless, many argue that the characteristics of the new black business community do not respond to the country's needs. The new black business elite is mostly composed of people with strong political credentials: Nthatho Motlana, 
chairman of NAIL and METLIFE, for example, was Nelson Mandela's personal physician. As they basically bring political capital, rather than managerial skills, black managers are very often sidelined in business structures, and find themselves confined to non-operational, public relations positions. Second, the re-creation of industrial conglomerates, albeit under a different racial ownership, does not seem to make sense following the opening of the South African economy. Third, corporate governance in some of the major companies taken over by black empowerment groups have been defective. The mishandlings that hit NAIL - by far the largest black group - in 1999 have received wide attention on the international press.

The response of traditional white business has been marked by a disengagement from South Africa. A primary listing abroad is therefore supposed to unlock some of the value currently forfeited by the fact that South African conglomerates trade at a discount to their net asset value, enhance a company's ability to procure international capital, and reduce the volatility of trading on a thin market such as the JSE. The first important issue was by Billiton, the world's second largest commodities group, which was listed in London in 1997. SAB followed in early 1999, and has subsequently taken advantage of its larger liquidity by becoming Central Europe's largest brewer and the world's fourth largest. In October 1998 Anglo launched an agreed takeover bid for Minorco, in which Anglo, De Beers, and the Oppenheimer family already had a combined $75 \%$ stake, and simplified its ownership structure. Anglo now comprises of six operational divisions and three big listed companies focused on gold (AngloGold), diamond s (De Beers), and platinum (Amplats). The restructuring left De Beers with only two main areas of interest - diamond mining and marketing, plus a $40 \%$ stake in Anglo, which in tum holds 33\% of De Beers. The Oppenheimer family's 9\% stake in Anglo allows it to maintain control over both companies. Following the London listing in May 1999, Anglo joined Billiton and SAB in the FTSE 100 index, and is now the world's largest nonoil mining company in terms of capitalization. Anglo has continued its divestiture strategy in South Africa, while increasing diversification abroad. Old Mutual and Sanlam became joint stock companies in 1998-99, with more than 5 million policy holders becoming shareholders. Mutualization was made conditional upon the transfer of a one-off levy of $2.5 \%$ of their free reserves to the Umsobomvu fund, investing in training and development programs for young people. Old Mutual is also listed in London. At an initial stage the government took a positive attitude, on the grounds that the change of listing of major South Africa companies could portend an increasing incoming revenue stream of dividend income and easier terms to fund new developments in the home country. In February 2000 the government published its criteria for the future. Consideration will be given in cases where:

- foreign expansion is necessary and integral to the company;

- the company derives abroad a significant proportion of revenue;

- there are clear monetary and balance of payments benefits. ${ }^{4}$

\footnotetext{
${ }^{4}$ Budget Speech, 23 February 2000.
} 
The market for corporate control has been buoyant in the second half of the 1990s. The numbers - R \$ 543 billion in 1996-98 alone - are, as a matter of fact, larger than for Brazil, but they are somehow inflated by methodological differences. Of the twenty largest South African deals reported in 1992-98, 75\% corresponds to the simplification of the corporate structure; $10 \%$ to consolidation in the financial industry; $10 \%$ to foreign acquisitions; and only one deal - Trans Natal's acquisition of Rand Coal to form Ingwe Coal in 1994 - is a "genuine" South African merger. The fact that South African conglomerates have made practically no large acquisitions in their own country is indeed remarkable. This holds true also for those sectors, like the utilities and internet-related investments, where familycontrolled business groups in OECD countries have been active even while refocusing their portfolios on the core business.

The other remarkable feature is that, notwithstanding its Anglo-Saxon business culture, South Africa has historically experienced little in the way of hostile takeovers, and those attempted have generally failed. Of great consequence is therefore the unsolicited offer made by Nedcor, a banking group, in November 1999 to acquire Stanbic. The Reserve Bank governor stepped into the fray urging the two banks to cool a war of words he said was tarnishing the sector's reputation. This was interpreted by the target as an inappropriate intervention. Stanbic also dragged the Finance minister into the battle, presenting a court affidavit arguing that he, not the registrar of banks, must consent to the bid. The Pretoria High Court ruled that the minister of Finance has the final say about the takeover, although he has to consult the Competition Commission. The ruling may speed up the process as it means that Nedcor's bid will not have to drag through a full scrutiny of the Competition Board as well as banking authorities.

\section{THE LIMITS OF CONVERGENCE}

Brazil and South Africa are not fully converging on the Anglo-American model of big business governance. It is true that private dispersed ownership, probusiness competition policy, and extreme market deregulation for public services appear to be gaining ground in both countries. However, and despite clear differences between South Africa and Brazil, both governments appear willing and able to keep a certain degree of autonomy to pursue a development strategy that is not agnostic to forms of ownership and market structure. This is not completely surprising, as in all countries the debate on concentration, competition, ownership, and corporate governance is embedded in the political economy, with concerns about economic power and social or economic justice predominant. As concerns the process of state divestiture in particular, this is a controversial process and it does not come as a surprise that governments use a variety of means to craft support for it. From this perspective, in this last section I analyze the three issues that are at the core of public actions in this domain: privatization and other ownership issues, competition policies, and the protection of domestic capital.

Relative to other emerging markets in South Africa state assets' divestiture was not given a high ranking. Political leadership is rather uncontentiously associated to 
both Cardoso and, it goes without saying, Mandela. ${ }^{5}$ Not much can be explained in terms of ideology, a factor that is, "at best, secondary in affecting the decision to privatize" (Manzetti 1999, p. 299). The most effective minister in South Africa in selling state assets, that of Transport, has been a life-long communist. This difference between Brazil and South Africa thus responds to the less immediate need for Pretoria authorities to finance large external and fiscal deficits. As suggested by Armijo (1998), pragmatic concerns over general economic governance are indeed the most important factors leading to the decision to privatize. South Africa never experienced the intense macroeconomic crisis that in Brazil (and even more so in other Latin American countries) tremendously improves the chances for radical reforms.

The second and related issue concerns the speed and embrace of competition policy reform and utilities liberalization. Differences between the two countries reflect both the pace of privatization and the role of liberalization in government's economic and social goals. Brazil has taken a more aggressive stance, as concern both economywide competition policy and telecoms liberalization, although less so in the energy sector. Authorities clearly saw the need to accompany privatization with reforms aimed at increasing economic efficiency and did not sacrifice longterm competition at the altar of short-term macroeconomic stabilization. In South Africa, on the other hand, competition policy has been reformed only recently. This partly reflects the relatively larger degree of mark et discipline imposed by higher import penetration, a natural outcome of the much smaller size of the domestic market. But, and perhaps more important, it also follows from the incorporation of wider socio economic goals - the advancement of the previously disadvantaged - into the agenda of a labor-backed government. Clearly this is the case in telecoms, where the willingness to assure a constant and sizeable stream of profits to foreign investors and black empowerment groups combines with the need to meet RDP targets in explaining the long monopoly granted to (partly-private) Telkom and the persisting duopoly in mobile telephony.

This paper, however, is not so much about the political economy of privatization as it is about the evolving nature of big business. First comes the issue of conglomerates. The great Transvaal houses founded by Cecil Rhodes and his successors, that dominated the economy for a century, are fast disappearing, to be replaced by focused operating companies with only a few dozen head office employees. Primary listing abroad and outward FOI - together with growing migration of skilled work force to OECD countries - have signalled the unease of white capital. While the market for corporate control has been buoyant recently, most new deals have been concluded within the framework of black empowerment, and very little has corresponded to privatization and inward FDI, exactly the forms of mergers and acquisi-

\footnotetext{
5 "Cardoso made coalition building his first priority. Having learned from Collor's mistakes, he engaged in a complicated strategy contemplating short-term payoffs appealing congressmen and governors in return for their support regarding privatizations that otherwise would have never got off the ground" (Manzetti 1999, p. 311). In the case of Mandela, political leadership refers more to the ability of steering South Africa towards a path of reconciliation than to his skills as a political operator, a task which he largely left to Mbeki.
} 
tions that account for most changes in corporate control in Brazil. Paradoxically, Brazilian conglomerates have become less, and not more, focused. While Vicunha provides a most extreme case, other Brazilian business groups have not behaved very differently. This seems to fit into the basic insight from the literature on business groups in developing economies, namely that this organizational form substitutes for missing markets and "that even with the best intentions, it takes longer than a decade to build the kind of institutions that can support well-functioning markets for capital, management, labor, and international technology" (Khanna and Palepu 1999, p. 126). The reverse of the coin is welfare-reducing exploitation of minority shareholders, as in many cases the complex shareholder structure and a jumble of non-core business interests have dragged the share price down.

In both countries, these developments are not without connection with the role of the government in shaping corporate restructuring. In the early phase when inflation control was far from assured, Brazilian authorities shied from the temptation of practicing "corporate re-engineering" as the risks of picking winners (or, more correctly, of creating losers) outweighed the possible benefits. Later on, the disrepute of the developmental state has not prevented BNDES from harboring the conviction that it knows where to lead private business. Since 1997, the bank has granted R $\$ 5.5$ billion of credits to Brazilian firms and consortia and $\mathrm{R} \$ 1.2$ billion to foreign investors. ${ }^{6}$ BNDES has also been pressing steel firms to pursue consolidation and has been concerned about the weakening of the Brazilian airline industry, urging the four large national carriers to consolidate. The involvement of the BNDES, and of the government more in general, has not been above controversies. Especially in 1997-98, concerns arose in some official circles that the process of economic opening and liberalization was proceeding too fast and that more state intervention was needed. This stance was also taken very forcefully by big business: Steinbruch (1998) clearly argues the case for a common public-private strategy to reinforce Brazilian groups in view of "realizing national objectives that are larger and stronger than simple corporate goals". These pressures led to the reinforcement of the Ministry for Development, Industry and Foreign Trade, although this proved an ill-fated attempt surpassed by events. The conditionality clauses imposed by the IMF both before and after the January 1999 crisis gave the upper hand to those in government that were skeptic about the desirability of such renewed interventionism. In early 2000 the government authorized foreign banks to bid for Banco do Estado de São Paulo (Banespa), and maintained its stance in the face of a broad alliance of desenvolvimentistas ranging from the Left to officials in previous military governments. ${ }^{7}$ Cardoso also sacked the president of the BNDES, who had been working with a group of São Paulo industrialists to try to set up a government-

\footnotetext{
${ }^{6}$ For example, in the privatization of Cesp Tietê- a São Paulo electricity generator - in October 1999, it supporred the US group AES, provoking the wrath of VBC (Votorantim, Bradesco, Camargo Corrêa), a rival Brazilian consortium. "O resgate de Tápias", Época, 31 January 2000.

7 “Presidente do 'Não”, Época, 14 February 2000. A poll by Folha de S. Paulo newspaper showed that $71 \%$ of those asked oppose letting foreigners buy Banespa; $58 \%$ think it does more harm than good to let foreign companies buy local ones
} 
sponsored petrochemicals giant. His replacement with a former president of the Central Bank of Brazil and chief executive for Latin America at a major international investment bank signals that people's capitalism through large-scale placements on financial markets will be the preferred option in forthcoming sell-offs.

In South Africa, the faith in the entrepreneurial state development model does not seem to be particularly high. Even those that question whether the commitment is real and the appreciation is deep acknowledge that the ANC has accepted the emerging global consensus on sound economic policies (COE 1999). Certainly, it refrained from the most activist stances, such as mandatory unbundling or nationalization, that some feared it could embrace to placate the pressure to do something about inequalities in economic power. On the other hand, even if the ANC government has taken a much more timid approach at affirmative action than the NP in the 1950s, the ethnic divide remains at the core of the political economy of capitalism. ${ }^{8}$ Optimists like to argue that, in the long run, black empowerment will create a new middle class centered on young black managers and other professionals. Moreover, black shareholders, particularly if they are unions' investment arms, should foster calmer labor relations. One problem is that so far black empowerment deals have clone little to establish genuine businesses. Because few blacks had much capital, banks lent money to well-connected black consortia that wanted to acquire shares in white businesses. The white firms offered their equity at a discount, because they thought that having black shareholders was politically sensible. The new black moguls were to repay their loans when their shares appreciated in value. No amount of financial engineering, however, can deal with the fundamental flaw of black empowerment, South African-style: that the emphasis has been almost entirely on taking over chunks of existing enterprises, rather than creating new ones. If anything, the huge sums poured into flashy, paper-shuffling empowerment deals has reduced the amount banks can spare for real black entrepreneurs.

\section{BIBLIOGRAPHY}

ANC (1992), Ready to Govern.

ARMIJO, L. (1993), “Brazilian Politics and Patterns of Financial Regulation, 1945-1991”, in S. Haggard, C. Lee and S. Maxfield (eds.), The Politics of Finance in Developing Countries, Cornell University Press.

(1998), "Balance Sheet or Ballot Box? Incentives to Privatize in Emerging Democracies", in P. Oxhorn and P. Starr (eds.), The Problematic Relationship between Economic Political Liberalization, Lynne Rienner.

\footnotetext{
${ }^{8} \mathrm{t}$ is interesting to note that the ANC affirmative action policies were drawn on the New Economic Policy framework adopted in the 1970s in Malaysia to empower the Bamiputras. Regardless of his merits and democratic credentials, Dr. Mohamad Mahathir is of course a very good example, possibly the best, of a statesman who has largely rejected the hypothesis that an emerging economy has to converge on the Anglo-Saxon model.
} 
BARR, G. J. GERSON, and B. KANTOR (1995), "Shareholders as Agents and Principals: The Case for South Africa's Corporate Governance System”, Journal of Applied Corporate Finance, vol. 8, no. 1.

BEBCHUCK, L. and M. ROE (1999), "A Theory of Path Dependence in Corporate Ownership and Governance”, Stanford Law Review, vol. 52, no. 1.

CDE (CENTRE FOR DEVELOPMENT AND ENTERPRISE) (1999), Policy-making in a new democracy. South Africa's challenges for the 21 " century.

CLARK, N. (1994), Manufacturing Apartheid. State Corporations in South Africa, Yale University Press. EVANS, P. (1979), Dependent Development, Princeton University Press.

GOLDIN, I. and C. HEYMANS (1999), "Moulding a new society: The RDP in perspective", in G. Maharaj (ed.), Between Unity and Diversity. Essays on Nation-building in Post-apartheid South Africa, IDASA and David Philip.

GOLDSTEIN, A. (1999), "Brazilian Privatization in Comparative Perspective: The Rocky Path from State Capitalism to Regulatory Capitalism”, Industrial and Corporate Change, vol. 8, no. 4.

(2000), "Big Business and the Wealth of South Africa: Policy Issues in the Transition from Apartheid”, mimeo, OECD Development Centre.

GUILLÉN, M. (1999), “Corporate Governance and Globalization: Arguments and Evidence against Convergence”, mimeo, The Wharton School and Department of Sociology, University of Pennsylvania.

HAGGARD, S., S. MAXFIELD and B. R. SCHNEIDER (1997), "Theories of Business and Business-State Relations”, in S. Maxfield and B. R. Schneider (eds.), Business and the State in Developing Countries, Cornell University Press.

KHANNA, T. and K. PALEPU (1999), "The Right Way to Restructure Conglomerates in Emerging Markets”, Harvard Business Review, July-August.

LIPTON, M. (1985), Capitalism and Apartheid, David Philip.

MANZETTI, L. (1999), Privatization South American Style, Oxford University Press.

MESQUITA MOREIRA, M. (1999), "Foreigners in an Open Economy: Recent Impacts on Productivity, Concentration and External Trade", mimeo, BNDES Economics Department.

MINISTRY FOR PUBLIC ENTERPRISES (1999), Public Enterprises Review 1994-1999.

NATTRASS, N. (1994a), “Apartheid and capitalism: social structure of accumulation or contradiction?”, in D. Kotz, T. McDonough, and M. Reich (eds.), Social Structures of Accumulation. The Political Economy of Growth and Crisis, Cambridge University Press.

(1994b), "Politics and Economics in ANC Economic Policy", African Affairs, vol. 93, no. 2.

(1999), "The Truth and Reconciliation Commission on Business and Apartheid: a Critical Evaluation", African Affairs, vol. 98, no. 3.

OLIVEIRA, G. (1998), "Is Antitrust Enforcement Possible in Latin America? The Regulator's Perspective", presentation at the Inter-American Dialogue, Washington, 26 June.

PAGANO, M. and P. VOLPIN (1999), "The Political Economy of Corporate Governance", CSEF Working Paper, no. 24, Università di Salerno.

SIFFERT FILHO, N. and C. SOUZA E SILVA (1999), "Large Companies in the 1990s: Strategic Responses to a Scenario of Change", mimeo, BNES Economics Department.

SINGH, A. (1995), "Corporate Financial Patters in Industrializing Economies”, IFC Technical Paper, no. 2.

STEINBRUCH, B. (1998), “O novo capitalismo brasileiro”, Folha de São Paulo, 26 May. 